\title{
A mathematical model for the study of contamination of honey with lead and cadmium in Baia Mare area
}

\section{Zoiţa Mărioara Berinde, Angela Mariana Michnea, Anamaria Gavra and Gheorghe Ardelean}

\begin{abstract}
.
Eleven samples of honey collected from different locations spread in the Baia Mare area and situated at various distances from the pollution source, the company Romplumb S.A. (while it has been in operation and after its closure in January 2012) were studied to determine the presence of the Pb and $\mathrm{Cd}$ by electrothermal atomic absorption spectrometry. It has been found that the concentration of lead and cadmium is generally correlated with the degree of pollution of the environment with these heavy metals, as well as with the distances from the pollution source and the directions of circulation of the contaminated air. In order to characterize the contamination of honey we introduced the index of contamination (IC) that shows a medium contamination for $\mathrm{Pb}$ and weak contamination for $\mathrm{Cd}$ in the period the pollution source was active and a weak contamination for $\mathrm{Pb}$ and no contamination for $\mathrm{Cd}$ after the closure of the metallurgical plant. We obtained a mathematical model representing the concentration of $\mathrm{Pb}$ in honey with respect to the geographical position in case the air was also contaminated with $\mathrm{Pb}$, and showing more clearly the influence of air flows on the contamination of honey.
\end{abstract}

\section{REFERENCES}

[1] Ajtony, Z., Bencs, L., Haraszi, R., Szigeti, J. and Szoboszlai, N., Study on the simultaneous determination of some essential and toxic trace elements in honey by multi-element graphite furnace atomic absorption spectrometry, Talanta, 71 (2007), 683-690

[2] Belouali, H., Bouaka, M. and Hakkou, A., Determination of some major and minor elements in the east of Morocco, honeys through inductively coupled plasma optical emission spectrometry, Apiacta, 43 (2008), 17-24

[3] Berinde, M. Z. and Michnea, A. M., A comparative study on the evolution of environmental and honey pollution with heavy metals, J. Science and Arts, 13 (2013), No. 2, 173-180

[4] Bodea, N., Bretan, L. and Mihaly-Cozmuta, A., Monitoring of honey's some quality parameters, Carpathian J. Food Sci. Techn., 1 (2009), No. $1,61-70$

[5] Bogdanov, S., Contaminants of bee products, Apidologie, 38 (2006), 1-18

[6] Bratu, I. and Georgescu, C., Chemical contamination of bee honey - identifying sensor of the environment pollution, J. Central Eur. Agriculture, 6 (2005), No. 1, 95-98

[7] Buldini, P. L., Cavalli, S., Mevoli, A. and Sharma, J. L., Ion chromatographic and voltammetric determination of heavy and transition metals in honey, Food Chemistry, 73 (2001), No. 4, 487-495

[8] Celli, G. and Maccagnani, B., Honey bees as bioindicators of environmental pollution, Bull. Insectol, 56 (2003), 137-139

[9] Conti, M. E. and Botre, F., Honeybees and their products as potential bioindicators of heavy metal contamination, Environmental Monitor. Assessment, 69 (2001), 267-282

[10] Erbilir, F. and Erdogrul, O., Determination of heavy metals in honey in Kahramanmaras city, Turkey, Environmental Monitor. Assessment, 109 (2005), 181-187

[11] Fredes, C. and Montenegro, G., Heavy metals and trace elements contents in Chilean honey, Ciencia e Investigacion Agrari, 33 (2006), No. 1, $50-58$

[12] Frias, I., Robio, C., Gonzalez-Iglesias, T., Gutierrez, J. A., Gonzalez-Weller, D. and Hardisson, A., Metals in fresh honey from Tenerife Island, Spain, Bull. Environmental Contamination and Toxicology, 80 (2008), 30-33

[13] Golob, T., Dobersek, U., Kump, P. and Necemer, M., Determination of trace and minor elements in Slovenian honey by total reflexion X-ray fluorescence spectroscopy, Food Chemistry, 91 (2004), No. 4, 593-600

[14] Gonzalez-Miret, M. L., Terrab, A., Hernanz, D., Fernandez-Recamales, M. A. and Heredia, F. J., Multivariate correlation between color and mineral composition of honeys and by their botanical origin, J. Agricultural and Food Chemistry, 53 (2005), No. 7, 2574-2580

[15] Jones, K. C., Honey as an indicator of heavy metal contamination, Water, Air and oil Pollution, 33 (1987), 179-189

[16] Pătruică, S., Jivan, A. and Hărmănescu, M., Researches regarding the mineral content of honey brands rise from Banat area, Bull. UASVM Animal Science and Biotechnologies, 65 (2008),No. (1-2), 446-449

[17] Perugini, M., Manera, M., Grotta, L., Abete, M. C., Tarasco, R. and Amorena, M., Heavy Metal (Hg, Cr, Cd, and Pb) Contamination in Urban Areas and Wildife Reserves: Honeybees as Bioindicators, Biological Trace Element Research, (2010), doi: 10.1007/s12011-010-8688-z

[18] Porrini, C., Sabatini, A. G., Girotti, S., Ghini, S., Medrzycki, P., Grillenzoni, F., Bortolotti, L.,Gattavecchia, E. and Celli, G., Honey bees and bee products as monitors of the environmental contamination, Apiacta, 38 (2003), 63-70

[19] Przybylowski, P. and Wilczynska, A., Honey as an environmental marker, Food Chemistry, 74 (2001), 289-291

[20] Sevlimli, H., Bayulgen, N. and Varinioglu, A., Determination of trace elements in honey by INAA in Turkey, J. Radioanalytical and Nuclear Chemistry, Letters 165 (5) (1992): 319-325, doi: 10.1007/BF02166150

[21] Staniškienè, B., Matusevičius, P. and Budreckienė, R., Honey as an Indicator of Environmental Pollution, Environmental research, engineering and management, 2 (2006), No. 36, 53-58

[22] Terrab, A., Recamales, F. A., Gonzales-Miret, M. L. and Heredia, F. J., Contribution to the study of avocado honeys by their mineral content using inductively coupled plasma optical emission spectrometry, Food Chemistry, 92 (2005), 305-309

[23] Tuzen, M., Silici, S., Mendil, D. and Soylak, M., Trace element levels in honeys from different regions of Turkey, Food Chemistry, 103 (2007), 325-330

[24] Vorlová, L. and Čelechovská, O., Activity of Enzymes and Trace Element Content in Bee Honey, Acta Vet. Brno, 71 (2002), 375-378

[25] Yarsan, E., Karacal, F., Ibrahim, I. G., Dikmen, B., Koksal, A. and Das, Y. K., Contents of some metals in honeys from different regions in Turkey, Bull. Environmental Contamination and Toxicology, 79 (2007), 255-258, doi: 10.1007/s00128-007-9034-9 
[26] Zugravu, C. A., Parvu, M., Patrascu, D. and Stoian, A., Correlations between lead and cadmium pollution of honey and environmental heavy metal presence in two Romanian counties, Bulletin UASVM Agriculture, 66 (2009), No. 2, 230-233

DEPARTMENT OF CHEMISTRY AND BIOLOGY

FACUlty OF SCIENCES North University Center at Baia Mare

TECHNICAL UNIVERSITY OF CLUJ-NAPOCA

VICTORIEI 76, 430122 BAIA MARE, ROMANIA

E-mail address: zoita_berinde@yahoo.com

Department of Mathematics AND Computer SCIENCE

Faculty of SCIEnces North University Center at Baia Mare

TECHNICAL UNIVERSITY OF CLUJ-NAPOCA

ViCTORIEI 76, 430122 BAIA MARE, ROMANIA

E-mail address: ardelean_g@yahoo.com

Environmental Protection Agency Maramures

IZA 1A 430073 BAIA MARE, ROMANIA

E-mail address: amichnea@yahoo.com 